\title{
Supplementation in mushroom crops and its impact on yield and quality
}

\author{
Jaime Carrasco ${ }^{1 *} \mathbb{0}$, Diego C. Zied ${ }^{2}$, Jose E. Pardo ${ }^{3}$, Gail M. Preston ${ }^{1}$ and Arturo Pardo-Giménez ${ }^{4}$
}

\begin{abstract}
Mushroom supplementation is an agronomic process which consists of the application of nutritional amendments to the substrates employed for mushroom cultivation. Different nitrogen and carbohydrate rich supplements have been evaluated in crops with a substantial impact on mushroom yield and quality; however, there is still controversy regarding the nutritional requirements of mushrooms and the necessity for the development of new commercial additives. The addition of external nutrients increases the productivity of some low-yielding mushroom varieties, and therefore is a useful tool for the industry to introduce new commercially viable varieties. Spent mushroom compost is a waste material that could feasibly be recycled as a substrate to support a new commercially viable crop cycle when amended with supplements. On the other hand, a new line of research based on the use of mushroom growth promoting microorganisms is rising above the horizon to supplement the native microbiota, which appears to cover nutritional deficiencies. Several supplements employed for the cultivated mushrooms and their agronomic potential in terms of yield and quality are reviewed in this paper as a useful guide to evaluate the nutritional requirements of the crop and to design new formulas for commercial supplementation.
\end{abstract}

Keywords: Substrate, Mushroom cultivation, Nutrition, Agronomy, Yield, Quality

\section{Introduction}

Most of the cultivated species of mushrooms belong to the phylum Basidiomycota, although some Ascomycota such as members from the genera Morchella or Tuber have also been successfully cultivated and commercially exploited (Rubini et al. 2014; Liu et al. 2017). Unlike plants, mushrooms are heterotrophic organisms which require external nutrients to grow; the vegetative mycelium (hypha network) supplies nutrients for the growth of basidiomes (reproductive stage) (Taylor and Ellison 2010). Mushrooms produce a number of enzymes including lignin-degrading enzymes (laccases, lignin peroxidases, manganese peroxidases, arylalcohol oxidase, aryl-alcohol dehydrogenases or quinone reductases), and hemicellulose and cellulose-degrading enzymes (xylanase, cellulases or cellobiose dehydrogenase), to facilitate the degradation of lignocellulosic substrates (Sánchez

\footnotetext{
*Correspondence: jaime.carrasco@plants.ox.ac.uk

${ }^{1}$ Department of Plant Sciences, University of Oxford, S Parks Rd,

Oxford OX1 3RB, UK

Full list of author information is available at the end of the article
}

2009; Kabel et al. 2017; Vos et al. 2017). Furthermore, mushrooms require oxygen and a specific $\mathrm{pH}$ in order to develop a normal metabolism and to grow properly. C and $\mathrm{N}$ are the two main macronutrients required by fungi for structural and energy requirements; $\mathrm{P}, \mathrm{K}$ and $\mathrm{Mg}$ are also considered macronutrients for mushrooms, in addition, trace elements such as $\mathrm{Fe}, \mathrm{Se}, \mathrm{Zn}, \mathrm{Mn}, \mathrm{Cu}$ and $\mathrm{Mo}$ appear to be needed for diverse functions (Chang and Miles 2004).

The initial phase of mushroom production consists of a solid fermentation process. From spawning, the vegetative mycelium grows under controlled environment and aseptic conditions to colonize the mass of substrate before fructifying (Zervakis and Koutrotsios 2017). There are two main formulas for the production of the substrates employed in mushroom cultivation that have been optimized depending on the species. Both are derived from agricultural by-products such as cereal straw, plant fiber/husk, manure or sawdust: 
1. Composted materials achieved through fermentation and pasteurization (Pardo et al. 2017; Kabel et al. 2017; Vos et al. 2017), designed for the cultivation of Agaricus bisporus (Lange) Imbach (AB) or A. subrufescens Peck (Pardo-Giménez et al. 2014; Pardo et al. 2017), Pleurotus ostreatus (Jacq: Fries) (PO), P. sajor-caju (Fr.) Singer or P. cistidiosus O.K. Mill. (Chang and Miles 2004; Sánchez 2010).

2. Non-composted materials that consist of a mixture of different agricultural by-products as the main ingredients, followed by steam sterilization of the substrate prior to the inoculation of the mycelium. Certain commercial species are produced employing this kind of substrate, including Lentinula edodes (Berk.) Pegler (LE), Auricularia sp., Flammulina velutipes (Curtis) Singer, Pleurotus eryngii (DC.: Fr.) Quel., Agrocybe aegerita (V. Brig.) Singer, Volvariella volvacea (Bull. Ex Fr.) or Hypsizygus marmoreus (Peck) Bigel (Chang and Miles 2004; Estrada et al. 2009; Liang et al. 2016; Xie et al. 2017; Kleofas et al. 2014; Yamanaka 2017).

Some cultivated species, like the globally cultivated white button mushroom (A. bisporus), require a casing overlay to cover the colonized substrate in order to induce mushroom fructification (Pardo-Giménez et al. 2017a).

Mushroom supplementation is understood as a farming method based on the physical addition of nutritional amendments to compost, during the process of composting, the mixture of raw materials, at spawning or during casing (Estrada et al. 2009; Pardo-Giménez et al. 2012a, 2016). The practice of nutritionally supplementing compost for mushroom cultivation at the time of spawning or casing to maximize crop yield emerged in the 1960s (Schisler and Sinden 1962; Sinden and Schisler 1962; Lemke 1963) and is widely recognized and accepted, however its use can be restricted in some sectors because of technical and economic factors. Important aspects to be considered include, on the one hand, the types of nutrients required and the most suitable time for them to be applied without forgetting, on the other hand, economic costs and profits (Randle 1985).

Recently, potential mushroom growth promoting (MGP) fungi and bacteria have been described to stimulate the mycelium growth and promote mushroom fructification, while constituting nitrogen or vitamins reservoirs (Zarenejad et al. 2012; Kertesz and Thai 2018). MGP therefore represent an additional form of supplement that could be supplied separately, or in combination with nutritional supplements, to increase crop yield.
The present mini-review compiles the recent advances on the supplementation of substrates employed in mushroom cultivation and aims to shed light on some agronomical aspects regarding this expanding crop (Zhang et al. 2014).

\section{Formulation of nutritional additives for mushroom cultivation}

Each mushroom species requires an optimal $\mathrm{C} / \mathrm{N}$ ratio in the substrate employed for cultivation, that allows growers to achieve the highest yield in the shortest period of production (Zied et al. 2011). Supplements are commonly manufactured products containing defatted vegetable meal, such as soybean meal, and other organic protein sources, among them cereal bran, enriched with minerals or vitamins, which are frequently used for the cultivation of Agaricus and Pleurotus species (Zied et al. 2011; Burton et al. 2015). There are a number of commercial supplements available for the producer in the market, most of them designed to supplement the phase II (at spawning) and phase III (at casing) substrate produced for the cultivation of $A$. bisporus. The commercial products mostly employed are produced by Amycel (Promycel ${ }^{\circledR}$, Titanium $^{\circledR}$, Ultimate $^{\circledR}$, etc.); Champfood (Champfood ${ }^{\circledR}$ ); Lambert (Full House $\left.{ }^{\circledR}\right)$, Havens $\left(\right.$ MCSubstradd $\left.^{\circledR}\right)$, Superchamp (Mix $\mathrm{P}^{\circledR}$ or Mix $\mathrm{V}^{\circledR}$ ), Nutrigain (Nutrigain Organic Gold ${ }^{\circledR}$ or Nutrigain MycroLiquid $\left.{ }^{\circledR}\right)$ and Everris $\left(\right.$ Micromax $\left.^{\circledR}\right)$, and are based on protein, lipid/protein blends, carboxylic acids or minerals (Burton et al. 2015).

In addition to these existing supplements, the use of low-cost agricultural by-products available at the productive regions is a promising approach. Among others, cereal meals and brans, chicken manure, cottonseed meal, urea, superphosphate, ammonium sulphate, grape pomace, feather flour or defatted meals from dry nuts, are recognized as active ingredients to supplement substrates employed in mushroom cultivation in Brazil or Europe (Zied et al. 2011; Pardo-Giménez et al. 2016, 2018). Following we summarize some of the most relevant results reported while employing agricultural wastes for mushroom supplementation:

Cultivation experiments on substrates supplemented with $20-40 \%$ composted or $20 \%$ raw two-phase olive mill waste ("alperujo") revealed a great potential for the cultivation of Pleurotus spp. and Agrocybe cylindracea while valorizing environmentally hazardous agricultural waste in Greece (Zervakis et al. 2013). Flammulina velutipes has been also cultivated in substrates with a high amount of alperujo, resulting in good biological efficiencies while minimizing the highly phytotoxic properties of this contaminating by-product (Rugolo et al. 2016).

Substrates based on grapeseed meal, defatted pistachio meal or defatted almond meal have shown 
similar agronomical behaviour to commercial additives for the cultivation of $A$. bisporus and P. ostreatus in Spain (Pardo-Giménez et al. 2012a, 2016, 2018). Supplement formula consisting of $25 \%$ of soybean, black bean, wheat bran and chia also showed good agronomical performance in substrates generated by self-heating pasteurization for the cultivation of $A$. bisporus (Colmenares-Cruz et al. 2017).

Trials conducted adding corn husk, oat husk, soy bean nuggets and peanut shell, in combination with soya as a nutritional supplement, to oyster mushrooms in strawbased substrates at spawning were reported to generate mushrooms with higher protein content (Jeyanthi Rebecca et al. 2015). Other local agricultural materials have been successfully employed as supplements in Iran for the cultivation of oyster mushroom, including wood chips, boll, sugar beet pellet pulp and palm fiber along with wheat bran, rice bran, soya cake powder, soya cake powder and rice bran and carrot pulp (Jafarpour et al. 2010).

\section{Application of mushroom supplements}

The correct timing and methods of application of supplements is an essential condition for obtaining the expected results, with several important culture aspects, such as the composting process, the control of temperature for mycelial growth before and after casing, the hygiene measures, the choice of supplement and its application time and, especially, the uniform distribution of the product used in the substrate, all affecting subsequent yields (Desrumaux et al. 1999).

To achieve a successful supplementation, particularly at spawning, it is necessary to design supplements which retard the availability of nutrients. The delayed-released nutrients where firstly reported by Carrol and Schisler (1976) through a treatment with formaldehyde. According to the authors formaldehyde limited the solubility and denatured the proteins of supplements, in addition it inhibited their availability for competitors moulds and then the mushroom mycelium could take the gradually accessible nutritional content when it became dominant within the mass of compost.

The increase in temperature immediately after supplementing should also be controlled. For instance, in modern facilities (equipped with air-conditioned growing-rooms and mechanized shelves to manage the crop) supplements can be added to the colonized compost just before applying the casing layer. Therefore, because environmental conditions can be controlled, excessive compost temperatures are avoided during spawn running, and the incidence of fungal competitors is minimized.
This also applies when the compost is incubated in tunnels at the composting plant (phase III). However, cropping in bags with phase II compost, the primary system used in many parts of the world, requires supplementation during spawning primarily due to mechanical restrictions (Pardo-Giménez et al. 2017b).

Therefore supplements, which are based on slow nutrient release formulas, can be applied at different points along the mushroom cropping cycle (Fig. 1). They are most commonly applied at the end of the substrate preparation, prior to spawning, to promote the vegetative growth throughout the substrate (Naraian et al. 2009), at the end of spawn run (with the substrate fully colonized by mushroom mycelium) to promote the mushroom colonization in the casing material (if required) and enhance mushroom fructification (Pardo-Giménez et al. 2016, 2018). However, the application of supplements along cropping has been also tested to increase the production of late flushes by supplementing the 2nd flush compost in A. bisporus (Royse and Chalupa 2009; Royse 2010).

\section{The nutritional content of mushrooms: effect of supplementation}

Cultivated mushrooms are a highly nutritious food that can be grown on biological wastes, agricultural wastes or agro-industrial wastes (Sánchez 2010; Atila 2017). Researchers have reported variations in the nutritional content of mushrooms cultivated on different substrates. When comparing the effects of different agro-wastes on the nutritional composition of oyster mushrooms and Pleurotus cystidiosus, formulas with $100 \%$ sugar bagasse and $100 \%$ corncob showed higher values of protein, fiber, ash and mineral content $(\mathrm{Ca}, \mathrm{K}$, and $\mathrm{Mg}$ ) than $100 \%$ sawdust (Hoa et al. 2015). The cultivation of Pleurotus ostreatus on various sawdust substrates was reported to give the best nutritional composition in mushrooms for the substrates based on fig tree sawdust, with the mushroom showing the highest amount of dry matter, lipid, nitrogen, iron, zinc and selenium; followed by a mixture of various sawdusts and an Ipil-ipil tree sawdust, all supplemented with $30 \%$ wheat bran and $1 \%$ lime (Bhattacharjya et al. 2015).

Furthermore, supplementation of substrates in $A$. bisporus with trace elements has been described as reliable for the production of fruiting bodies enriched with $\mathrm{Se}, \mathrm{Cu}$ and $\mathrm{Zn}$ (Werner and Beelman 2002; Rzymski et al. 2017), micronutrients that frequently are deficient in the human diet (Bird et al. 2017).

\section{Implications on yield and quality}

The formula employed for the design of the substrate deeply influences the yield and quality of the basidiomes harvested (Moonmoon et al. 2011; He et al. 2018). 


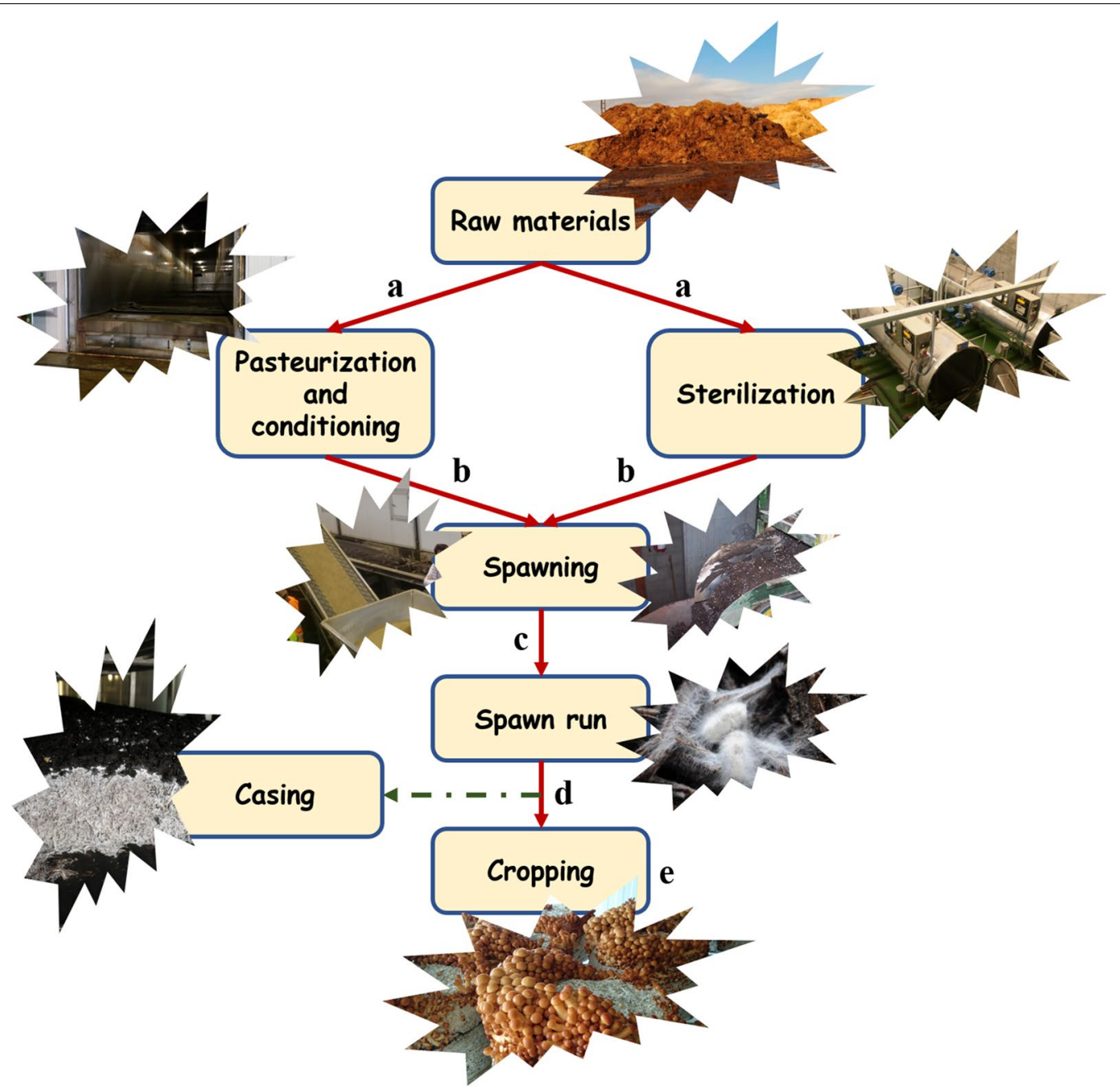

Fig. 1 Nutritional supplementation of substrates along different stages of mushroom cultivation. a Application to raw materials; b, c Addition during spawning (after pasteurization/sterilization of substrates); d Supplementation of colonized substrates; e Supplementation during the cropping stage

Compost supplementation with defatted pistachio meal and defatted almond meal significantly improved the quality of white button mushroom, A. bisporus, (larger mushrooms with firmer texture and greater content in dry weight and protein) and increased more than $30 \%$ the yield in oyster mushroom, $P$. ostreatus, in comparison to non-supplemented substrates (Pardo-Giménez et al. 2016, 2018). Sawdust supplemented with different levels of wheat bran, rice bran or maize powder improved yield and quality of Lentinula edodes, with $25 \%$ wheat bran and $40 \%$ wheat bran reported as the best rate to obtained highest yield and best quality respectively (Moonmoon et al. 2011). Among four different formulas evaluated, the addition of Morchella spp. footing soil had the optimal effect on promoting the growth and quality of Morchella spp. among four different formulas (He et al. 2018). Finally, Pleurotus species produced on substrates containing grape marc or olive mill wastes showed higher content of bioactive compounds and comparable productivity than wheat-based substrates (Koutrotsios et al. 2018).

\section{Supplementation of spent mushroom compost as a recycling material for the cultivation of mushroom species}

The annual production of spent mushroom substrate (SMS), the agricultural waste derived from mushroom production, is estimated around 170-204 billion $\mathrm{kg}$ in 2013 (Ma et al. 2014; Royse et al. 2017). Among the different uses described for spent mushroom compost (Rinker 2017), the recycling of the SMS through amendment with 
nutritional supplements to support further mushroom production is a viable alternative to cope with the high volume of this waste material (Pardo-Giménez et al. 2011, 2012b). When the SMS from P. ostreatus is supplemented with a protein-rich product, such as commercial supplements (Calprozime ${ }^{\circledR}$, Champfood ${ }^{\circledR}$ or Promycel $600^{\circledR}$ ), the total nitrogen content in the substrate increases, and consequently, the values of the crude protein content and the neutral detergent-soluble fraction (Picornell-Buendía et al. 2016a). Substrate formulations with material based on wheat straw and spent Pleurotus substrates supplemented with wheat bran and the commercial supplement (Calprozime ${ }^{\circledR}$ ) have shown good agronomic performance for $P$. ostreatus, with supplemented mixtures producing mushrooms of higher protein and ash content (PicornellBuendía et al. 2016b). In addition, quantitative parameters, such as good biological efficiency (BE), high quantity of mushrooms and an excellent unit weight of the fruiting bodies have been achieved with this supplemented SMS when employed to re-grow P. ostreatus (PicornellBuendía et al. 2015). Therefore, spent mushroom substrates supplemented with protein-rich additives can be potentially employed as a cheap base material to grow $P$. ostreatus and simultaneously implement a circular economy based on the integral management of wastes.

\section{New varieties of cultivated mushrooms to diversify the industry: Agaricus subrufescens}

Five different genera constitute $85 \%$ of the world's cultivation of edible mushrooms: Lentinula edodes (shiitake), Agaricus (mainly Agaricus bisporus), Pleurotus spp. (5 or 6 species), Auricularia and Flammulina (Royse et al. 2017). Supplementation has been reported to improve yield and quality of most cultivated species worldwide, including the above cited species (Fig. 2) (Sánchez 2010; Gaitán-Hernández et al. 2014; Liang et al. 2016; PardoGiménez et al. 2016, 2018; Xie et al. 2017). Although many other varieties have been successfully cultivated (Carrasco et al. 2018), some of them present commercial limitations due to the reduced yield achieved. Supplementation represents an important strategy to improve the yield and commercial viability of these less widely cultivated varieties.

For example, the practice of supplementation has been an important approach for improving yield in the industrial production of the medicinal mushroom Agaricus subrufescens (also known as the sun mushroom) Ellis \& Everh (Zied et al. 2018), and therefore is an opportunity to make this new variety commercially viable to diversify the industry. Kopytoswky-Filho et al. (2008) evaluated the effect of supplementation in cultivation of $A$. subrufescens, reporting a significant increase of production with the soybean meal-based commercial supplement Champfood $^{\circledR}$ applied before casing with respect to not supplemented (control) and soybean supplemented. The use of soybean meal and other by-products from soybean transformation, such as commercial formulations, was also reported to have positive effect in the cultivation of sun mushroom by Zied et al. (2011), Wang et al. (2010), Zhou et al. (2010). In addition, waste materials, including agro-industrial waste (provided by peanut and acerola juice) and noble grains, a mix with bran of soybean, corn, and cotton have been proved effective to increase the industrial yield, which highlights materials with high $\mathrm{S}, \mathrm{Cu}$, and $\mathrm{Mn}$ contents as ideal supplements (Zied et al. 2018).

\section{Bioinoculants as an alternative or addition to traditional supplementation}

Like nutritional supplements it is likely that different bioinoculants can be developed to support mushroom growth at different stages of crop development. Certain microbiota, including bacteria from the genera Azotobacter, Bacillus, Paenibacillus and Pseudomonas, described increasing the mycelial growth of cultivated species while showing antagonism against competitive molds, have been reported as candidates for the design of alternative nutritional supplements/biofertilizers (Payapanon et al. 2011; Jadhav et al. 2014; Pratiksha et al. 2017). A good number of bacteria from the genera Bacillus, Pseudomonas or Bradyrhizobium appear to stimulate the mycelial growth of some cultivated species (A. bisporus, $A$. bitorquis, $A$. subrufescens, $P$. ostreatus or $P$. eryngii) in compost or in vitro, and others have been described to favor and enhance mushroom fructification in casing, such as members from the genera Pseudomonas (Kertesz and Thai 2018). In addition, he colonization of the thermophilic fungus Mycothermus thermophilus (Scytalidium thermophilum), at the conditioning stage of phase II composting has been described as important for stimulating growth, development and yield of $A$. bisporus and for increasing selectivity of the substrate (Sánchez et al. 2008; Coello-Castillo et al. 2009; Natvig et al. 2015).

Although there are an increasing number of commercial biofertilizers based on bacterial and fungal plant growth promoters (Goswami et al. 2016), to date there are no commercial supplements based on mushroom growth promoting microorganisms available in the market. Next generation sequencing (NGS) is a highthroughput technology that is currently providing a rich source of information about the microorganisms inhabiting the substrates employed in mushroom cultivation and the structure and dynamics of the native microbiota (McGee et al. 2017a, b; Kertesz and Thai 2018; Vieira and Pecchia 2018; our unpublished results). 

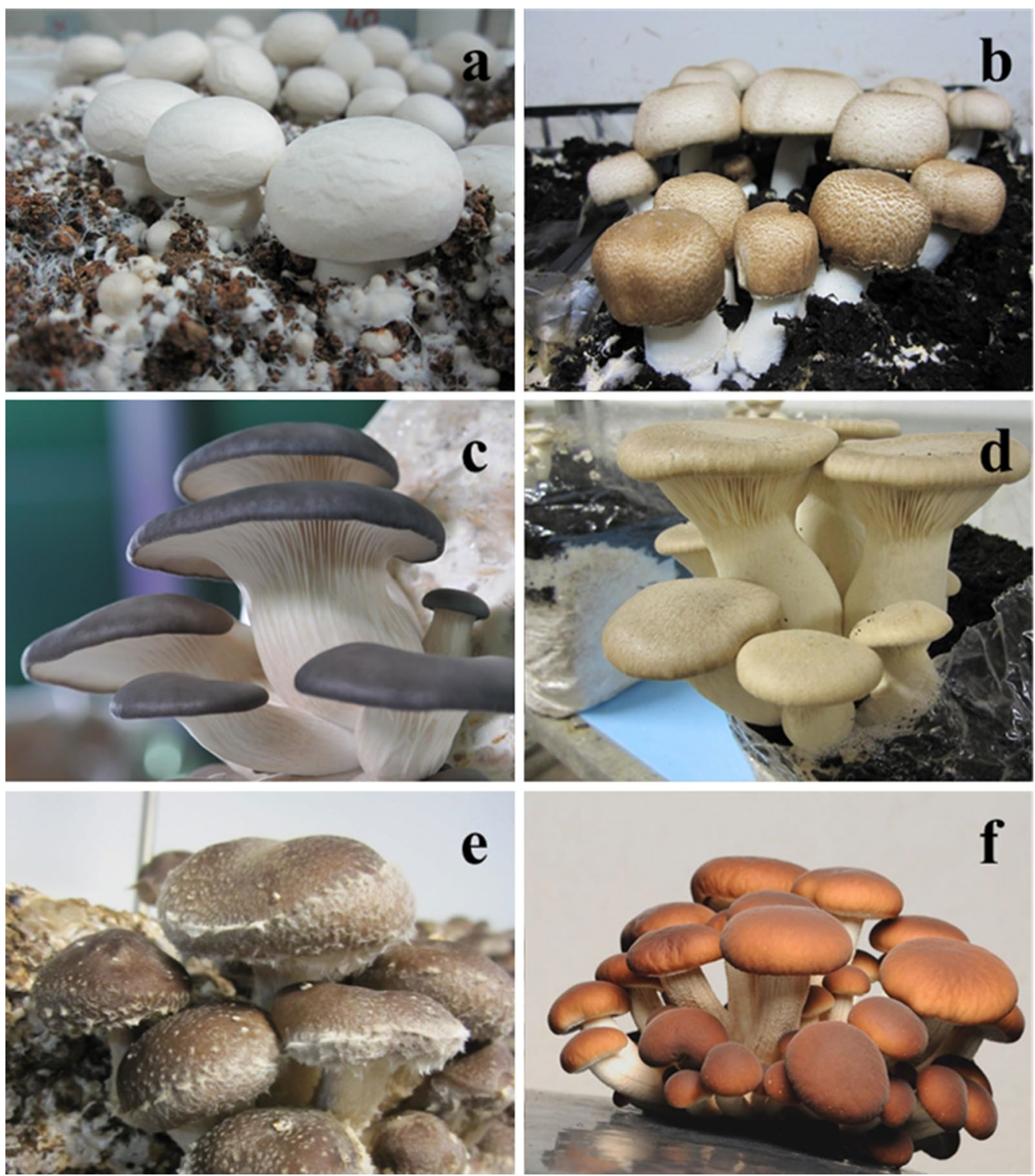

Fig. 2 Production of mushrooms on supplemented substrates. a Agaricus bisporus; b Agaricus subrufescens; c Pleurotus ostreatus; $\mathbf{d}$ Pleurotus eryngii; e Lentinula edodes; $\mathbf{f}$ Agrocybe aegerita

The Omics approach with tools such as metagenomics (to detect and quantify the relative abundance of microorganisms by DNASeq), metatranscriptomics (to study the function and activity through RNASeq) and metabolomics (to characterize metabolites involved with analytical techniques) can set the basis for the development of bioinoculants for the industry while discriminating the most suitable point of application along the crop cycle.

\section{Overview and perspectives}

The agronomic practice of nutritionally supplementing mushroom cultivation is cost effective to improve crop yield and quality; however technical or economical issues limits its globally spread.

The majority of supplements sold commercially are currently based on nitrogen rich compounds, and it is currently unclear whether the use of low-protein supplements based on carbon-rich sources such as cellulose and hemicellulose components improves the performance of the mushroom equally or even more than nitrogen addition. In comparison to protein-rich 
components, ingredients with high content of carbohydrates, such as agricultural and commercial waste products, are cheaper and readily available in local producing areas (Pardo-Giménez et al. 2016). However, it is noteworthy that the use of commercially available protein-based nutrients is a profitable investment since mushroom yield consistently increases and ultimately also mushroom quality. Besides, the use of nutritional additives is a useful tool to partially recycle the SMS into new growth cycles, in an effort to building a circular economy involving waste management, and to increase the biological efficiency of alternative cultivated species in order to diversify the industry. Although the interactions among mushrooms and their environmental niche has been barely described, microorganisms play an important role in different stages of mushroom cultivation, and therefore future prospects for improving mushroom yield would benefit from deepening the knowledge of the structure, role and dynamics of the mushroom microbiome with the aim of developing supplements based on bioinoculants for mushroom crops.

\section{Abbreviations}

SMS: spent mushroom compost; MGP: mushroom growth promoting; NGS: next generation sequencing; DNASeq: DNA sequencing; RNASeq: RNA sequencing.

\section{Authors' contributions}

Conceptualization: JC; Literature review: JC; Data curation: JC, DCZ, APG Writing: JC, APG; Figures: JC, APG; Funding: JC, DCZ, GMP; Validation: JC, DCZ, JEP, GMP, APG; Review \& editing: JC, DCZ, JEP. GMP, APG. All authors read and approved the final manuscript.

\section{Author details}

1 Department of Plant Sciences, University of Oxford, S Parks Rd, Oxford OX1 3RB, UK. ${ }^{2}$ Universidade Estadual Paulista (UNESP), Câmpus de Dracena, Dracena, São Paulo 17900-000, Brazil. ${ }^{3}$ Escuela Técnica Superior de Ingenieros Agrónomos y de Montes (ETSIAM), Universidad de Castilla-La Mancha, Campus Universitario, s/n, 02071 Albacete, Spain. ${ }^{4}$ Centro de Investigación, Experimentación y Servicios del Champiñón, Quintanar del Rey, Cuenca, Spain.

\section{Acknowledgements}

The project leading to this report has received funding from the European Union's Horizon 2020 research and innovation programme under the Marie Sklodowska-Curie grant agreement No 742966, and the Fundação de Amparo à Pesquisa do Estado de São Paulo (Brazil), reference process 2015/15306-3.

\section{Competing interests}

The authors declare that they have no competing interests.

\section{Availability of data and materials \\ Data and material regarding the material reported as self-citation by the authors in this Mini-review is available upon request.}

\section{Consent for publication}

All are aware of its submission to the Journal and its publication.

\section{Ethics approval and consent to participate}

There are no mandatory ethics documents associated with this Project. The research project has been implemented and managed in accordance with the general principles and requirements of the European Charter for Councils. The
Charter provides a framework for researchers, employers and funders to act responsibly and professionally.

The present project is based on the commitment from the Marie-Curie Fellow (Marie Sklodowska-Curie grant agreement No 742966) to share the advances achieved with the industry and the scientific community.

All are aware of its submission to the Journal.

\section{Funding}

1. Horizon 2020 (European Comission): Marie Sklodowska-Curie grant agreement No 742966 (Fellow: Jaime Carrasco).

2. Fundação de Amparo à Pesquisa do Estado de São Paulo (Brazil), reference process 2015/15306-3 (PI: Diego Cunha Zied).

\section{Publisher's Note}

Springer Nature remains neutral with regard to jurisdictional claims in published maps and institutional affiliations.

Received: 19 July 2018 Accepted: 14 September 2018

Published online: 18 September 2018

\section{References}

Atila F (2017) Evaluation of suitability of various agro-wastes for productivity of Pleurotus djamor, Pleurotus citrinopileatus and Pleurotus eryngii mushrooms. J Exp Agric Int 17(5):1-11. https://doi.org/10.9734/ JEAI/2017/36346

Bhattacharjya DK, Paul RK, Miah MN, Ahmed KU (2015) Comparative study on nutritional composition of oyster mushroom (Pleurotus ostreatus Fr.) cultivated on different sawdust substrates. Biores Commun 1(2):93-98

Bird JK, Murphy RA, Ciappio ED, McBurney MI (2017) Risk of deficiency in multiple concurrent micronutrients in children and adults in the United States. Nutrients 9(7):655. https://doi.org/10.3390/nu9070655

Burton K, Noble R, Rogers S, Wilson J (2015) Understanding mushroom nutrition: project aimed at improving yield, substrate efficiency and utilisation and flavor. M056 Final Report. Agriculture and Horticulture Development Board (AHDB). p 54

Carrasco J, Tello ML, Pérez-Clavijo M, Preston G (2018) Biotechnological requirements for the commercial cultivation of macrofungi: substrate and casing layer, Chapter 7. In: Singh BP, Chhakchhuak L (eds) Biology of macrofungi. Springer, Berlin (in press)

Carrol AD Jr, Schisler LC (1976) Delayed release nutrient supplement for mushroom culture. Appl Environ Microbiol 31:499-503

Chang S, Miles PG (2004) Mushrooms: cultivation, nutritional value, medicinal effect and environmental impact, 2nd edn. CRC Press, Boca Raton. ISBN 0-8493-1043-1

Coello-Castillo MM, Sánchez JE, Royse DJ (2009) Production of Agaricus bisporus on substrates pre-colonized by Scytalidium thermophilum and supplemented at casing with protein-rich supplements. Bioresour Technol 100(19):4488-4492. https://doi.org/10.1016/j.biortech.2008.10.061

Colmenares-Cruz S, Sánchez JE, Valle-Mora J (2017) Agaricus bisporus production on substrates pasteurized by self-heating. AMB Express 7(1):135. https://doi.org/10.1186/s13568-017-0438-6

Desrumaux B, Seydeyn P, Werbrouck A, Lannoy P (1999) Supplémenter dans la culture du champignon de couche: experience comparative avec quelques produits de supplementation du commerce. Bull FNSACC 81:789-802

Estrada AER, Jimenez-Gasco MM, Royse DJ (2009) Improvement of yield of Pleurotus eryngii var. eryngii by substrate supplementation and use of a casing overlay. Bioresour Technol 100:5270-5276. https://doi. org/10.1016/j.biortech.2009.02.073

Gaitán-Hernández R, Cortés N, Mata G (2014) Improvement of yield of the edible and medicinal mushroom Lentinula edodes on wheat straw by use of supplemented spawn. Braz J Microbiol 45(2):467-474. https://doi. org/10.1590/S1517-83822014000200013

Goswami D, Thakker JN, Dhandhukia PC (2016) Portraying mechanics of plant growth promoting Rhizobacteria (PGPR): a review. Cogent Food Agric 2(1):1127500. https://doi.org/10.1080/23311932.2015.1127500 
He S, Zhao K, Ma L, Yang J, Chang Y (2018) Effects of different cultivation material formulas on the growth and quality of Morchella spp. Saudi J Biol Sci 25(4):719-723. https://doi.org/10.1016/j.sjbs.2017.11.021

Hoa HT, Wang CL, Wang CH (2015) The effects of different substrates on the growth, yield, and nutritional composition of two oyster mushrooms (Pleurotus ostreatus and Pleurotus cystidiosus). Mycobiology 43(4):423-434. https://doi.org/10.5941/MYCO.2015.43.4.423

Jadhav AC, Shinde DB, Nadre SB, Deore DS (2014) Quality improvement of casing material and yield in milky mushroom (Calocybe indica) by using biofertilizers and different substrates. In: Proceedings of 8 th international conference on mushroom biology and mushroom products (ICMBMP8). ICAR-Directorate of Mushroom Research, Solan, India. pp 359-364

Jafarpour M, Jalali A, Dehdashtizadeh B, Eghbalsaied S (2010) Evaluation of agricultural wastes and food supplements usage on growth characteristics of Pleurotus ostreatus. Afr J Agric Res 5(23):3291-3296. https://doi. org/10.5897/AJAR10.623

Jeyanthi Rebecca L, Seshiah C, Kowsalya E, Sharmila S (2015) Effect of food processing waste on the growth and nutrition quality of Pleurotus ostreatus. Int J Pharm Technol 7(2):8887-8893

Kabel MA, Jurak E, Mäkelä MR, de Vries RP (2017) Occurrence and function of enzymes for lignocellulose degradation in commercial Agaricus bisporus cultivation. Appl Microbiol Biot 101:4363-4369. https://doi.org/10.1007/ s00253-017-8294-5

Kertesz MA, Thai M (2018) Compost bacteria and fungi that influence growth and development of Agaricus bisporus and other commercial mushrooms. Appl Microbiol Biotechnol 102:1639-1650. https://doi. org/10.1007/s00253-018-8777-z

Kleofas V, Sommer L, Fraatz MA, Zorn H, Rühl M (2014) Fruiting body production and aroma profile analysis of Agrocybe aegerita cultivated on different substrates. Nat Res 5:233-240. https://doi.org/10.4236/nr.2014.56022

Kopytowski Filho J, Minhoni MTA, Andrade MCN, Zied D (2008) Effect of compost supplementation (soybean meal and Champfood) at different phases (spawning and before casing) on productivity of Agaricus blazei. Mush Sci 17:260-270

Koutrotsios G, Kalogeropoulos N, Kaliora AC, Zervakis G (2018) Towards an increased functionality in oyster (Pleurotus) mushrooms produced on grape marc or olive mill wastes serving as sources of bioactive compounds. J Agric Food Chem 66(24):5971-5983. https://doi.org/10.1021/ acs.jafc.8b01532

Lemke G (1963) Champignonkultur auf nicht kompostiertem Strohsubstrat mit "Startddungung". Die Deutsche Gartenbauwirtschaft 11:167-169

Liang CH, Wu CY, Lu PL, Kuo YC, Liang ZC (2016) Biological efficiency and nutritional value of the culinary-medicinal mushroom Auricularia cultivated on a sawdust basal substrate supplement with different proportions of grass plants. Saudi J Biol Sci. https://doi.org/10.1016/j.sjbs.2016.10.017

Liu Q, Ma H, Zhang Y, Dong C (2017) Artificial cultivation of true morels: current state, issues and perspectives. Crit Rev Biotechnol 38(2):259-271. https:// doi.org/10.1080/07388551.2017.1333082

Ma Y, Wang Q, Sun X, Wang X, Su W, Song N (2014) A study on recycling of spent mushroom substrate to prepare chars and activated carbon. BioResources 9(3):3939-3954

McGee CF, Byrne H, Irvine A, Wilson J (2017a) Diversity and dynamics of the DNA-and CDNA-derived compost fungal communities throughout the commercial cultivation process for Agaricus bisporus. Mycologia 109:475-484. https://doi.org/10.1080/00275514.2017.1349498

McGee CF, Byrne H, Irvine A, Wilson J (2017b) Diversity and dynamics of the DNA and cDNA-derived bacterial compost communities throughout the Agaricus bisporus mushroom cropping process. Ann Microbiol 67:751-761. https://doi.org/10.1007/s13213-017-1303-1

Moonmoon M, Shelly NJ, Khan MA, Uddin MN, Hossain K, Tania M, Ahmed S (2011) Effects of different levels of wheat bran, rice bran and maize powder supplementation with saw dust on the production of shiitake mushroom (Lentinus edodes (Berk.) Singer). Saudi. J Biol Sci 18(4):323-328. https://doi.org/10.1016/.j.jbs.2010.12.008

Naraian R, Sahu RK, Kumar S, Garg SK, Singh CS, Kanaujia RS (2009) Influence of different nitrogen rich supplements during cultivation of Pleurotus florida on corn cob substrate. Environmentalist 29(1):1-7. https://doi. org/10.1007/s10669-008-9174-4

Natvig DO, Taylor JW, Tsang A, Hutchinson MI, Powell AJ (2015) Mycothermus thermophilus gen. et comb. nov., a new home for the itinerant thermophile Scytalidium thermophilum (Torula thermophila). Mycologia 107(2):319-327. https://doi.org/10.3852/13-399

Pardo JE, Zied DC, Alvarez-Ortí M, Peñaranda JA, Gómez-Cantó C, PardoGiménez A (2017) Application of hazard analysis and critical control points (HACCP) to the processing of compost used in the cultivation of button mushroom. Int J Recycl Org Waste Agric 6:179-188. https://doi. org/10.1007/s40093-017-0160-z

Pardo-Giménez A, Pardo-Gonzalez JE, Cunha Zied D (2011) Evaluation of harvested mushrooms and viability of Agaricus bisporus growth using casing materials made from spent mushroom substrate. Int J Food Sci Technol 46:787-792. https://doi.org/10.1111/j.1365-2621.2011.02551.x

Pardo-Giménez A, Zied DC, Álvarez-Ortí M, Rubio M, Pardo JE (2012a) Effect of supplementing compost with grapeseed meal on Agaricus bisporus production. J Sci Food Agric 92(8):1665-1671. https://doi.org/10.1002/ jsfa.5529

Pardo-Giménez A, Picornell Buendia MR, de Juan Valero JA, Pardo-Gonzalez JE, Cunha Zied D (2012b) Cultivation of Pleurotus ostreatus using supplemented spent oyster mushroom substrate. Acta Hortic 933:267-272. https://doi.org/10.17660/ActaHortic.2012.933.33

Pardo-Giménez A, Pardo JE, Carrasco J, Álvarez-Ortí M, Zied DC (2014) Use of Phase II mushroom compost in Agaricus subrufescens production. In: Proceedings of 8th International Conference on Mushroom Biology and Mushroom Products (ICMBMP8). ICAR-Directorate of Mushroom Research, Solan, India. pp 516-522

Pardo-Giménez A, Catalán L, Carrasco J, Álvarez-Ortí M, Zied D, Pardo J (2016) Effect of supplementing crop substrate with defatted pistachio meal on Agaricus bisporus and Pleurotus ostreatus production. J Sci Food Agric 96(11):3838-3845. https://doi.org/10.1002/jsfa.7579

Pardo-Giménez A, Pardo JE, Zied DC (2017a) Casing materials and techniques in Agaricus bisporus cultivation. In: Zied DC, Pardo-Giménez A (eds) Edible and medicinal mushrooms: technology and applications. Wiley, Hoboken, pp 385-413. https://doi.org/10.1002/9781119149446.ch7

Pardo-Giménez A, Pardo JE, Zied DC (2017b) Supplementation of high nitrogen Agaricus compost: yield and mushroom quality. J Agr Sci Tech 19:1589-1601

Pardo-Giménez A, Carrasco J, Roncero JM, Álvarez-Ortí M, Zied DC, PardoGonzález JE (2018) Recycling of the biomass waste defatted almond mea as a novel nutritional supplementation for cultivated edible mushrooms. Acta Sci Agro 40:e39341. https://doi.org/10.4025/actasciagron.v40i1 .39341

Payapanon A, Suthirawut S, Shompoosang S, Tsuchiya K, Furuya N, Roongrawee P, Kulpiyawati T, Somrith A (2011) Increase in yield of the straw mushroom (Vovariella volvacea) by supplement with Paenibacillus and Bacillus to the compost. J Faculty Agric Kyushu University 56:249-254

Picornell-Buendía MR, Pardo A, de Juan JA (2015) Reuse of degraded Pleurotus ostreatus substrate through supplementation with wheat bran and Calprozime ${ }^{\circledR}$ quantitative parameters. Agron Colomb 33(2):261-270. https://doi.org/10.1111/jfq.12216

Picornell-Buendía MR, Pardo-Giménez A, de Juan-Valero JA (2016a) Qualitative parameters of Pleurotus ostreatus (jacq.) p. kumm mushrooms grown on supplemented spent substrate. J Soil Sci Plant Nutr 16(1):101-117. https ://doi.org/10.4067/s0718-95162016005000008

Picornell-Buendía MR, Pardo-Giménez A, Juan-Valero D, Arturo J (2016b) Agronomic qualitative viability of spent Pleurotus substrate and its mixture with wheat bran and a commercial supplement. J Food Quality 39(5):533-544. https://doi.org/10.1111/jfq.12216

Pratiksha K, Narute TK, Surabhi S, Ganesh A, Sujoy S (2017) Effect of liquid biofertilizers on the yield of button mushroom. J Mycopathol Res 55:135-141

Randle PE (1985) Supplementation of mushroom composts-a review. Mushroom J 151:241-249

Rinker DL (2017) Spent mushroom substrate uses. In: Zied DC, Pardo-Giménez A (eds) Edible and medicinal mushrooms: technology and applications. Wiley, Hoboken, pp 427-454. https://doi.org/10.1002/9781119149446. ch20

Royse DJ (2010) Effects of fragmentation, supplementation and the addition of phase II compost to 2 nd break compost on mushroom (Agaricus bisporus) yield. Bioresour Technol 101(1):188-192. https://doi.org/10.1016/j. biortech.2009.07.073

Royse DJ, Chalupa W (2009) Effects of spawn, supplement, and phase II compost additions and time of re-casing second break compost 
on mushroom (Agaricus bisporus) yield and biological efficiency. Bioresour Technol 100(21):5277-5282. https://doi.org/10.1016/j.biort ech.2009.02.074

Royse DJ, Baars J, Tan Q (2017) Current overview of mushroom production in the world. In: Zied DC, Pardo-Giménez A (eds) Edible and medicina mushrooms: technology and applications. Wiley, Hoboken, pp 5-13. https://doi.org/10.1002/9781119149446.ch2

Rubini A, Riccioni C, Belfiori B, Paolocci F (2014) Impact of the competition between mating types on the cultivation of Tuber melanosporum: Romeo and Juliet and the matter of space and time. Mycorrhiza 24(1):19-27. https://doi.org/10.1007/s00572-013-0551-6

Rugolo M, Levin L, Lechner BE (2016) Flammulina velutipes: an option for "alperujo" use. Rev Iberoam Micol 33(4):242-247. https://doi.org/10.1016/j. riam.2015.12.001

Rzymski P, Mleczek M, Niedzielski P, Siwulski M, Gąsecka M (2017) Cultivation of Agaricus bisporus enriched with selenium, zinc and copper. J Sci Food Agric 97(3):923-928. https://doi.org/10.1002/jsfa.7816

Sánchez C (2009) Lignocellulosic residues: biodegradation and bioconversion by fungi. Biotechnol Adv 27:185-194. https://doi.org/10.1016/j.biote chadv.2008.11.001

Sánchez C (2010) Cultivation of Pleurotus ostreatus and other edible mushrooms. Appl Microbiol Biotechnol 85:1321-1337. https://doi.org/10.1007/ s00253-009-2343-7

Sánchez JE, Mejia L, Royse DJ (2008) Pangola grass colonized with Scytalidium thermophilum for production of Agaricus bisporus. Bioresour Technol 99(3):655-662. https://doi.org/10.1016/j.biortech.2006.11.067

Schisler LC, Sinden JW (1962) Nutrient supplementation of mushroom compost at spawning. Mushroom Sci 5:150-164

Sinden JW, Schisler LC (1962) Nutrient supplementation of mushroom compost at casing. Mushroom Sci 5:267-280

Taylor JW, Ellison CE (2010) Mushrooms: morphological complexity in the fungi. PNAS 107(26):11655-11656. https://doi.org/10.1073/pnas.10064 30107

Vieira FR, Pecchia JA (2018) An exploration into the bacterial community under different pasteurization conditions during substrate preparation (composting-Phase II) for Agaricus bisporus cultivation. Microb Ecol 75:318-330. https://doi.org/10.1007/s00248-017-1026-7

Vos AM, Jurak E, Pelkmans JF, Herman K, Pels G, Baars JJ, Hendriz E, Kabel MA, Lugones LG, Wösten HA (2017) $\mathrm{H}_{2} \mathrm{O}_{2}$ as a candidate bottleneck for MnP activity during cultivation of Agaricus bisporus in compost. AMB Expr 7:124. https://doi.org/10.1186/s13568-017-0424-z

Wang Q, Li BB, Li H, Han JR (2010) Yield, dry matter and polysaccharides content of the mushroom Agaricus blazei produced on asparagus straw substrate. Sci Hort 125:16-18. https://doi.org/10.1016/j.scien ta.2010.02.022

Werner AR, Beelman RB (2002) Growing high-selenium edible and medicinal button mushrooms (Agaricus bisporus (J. Lge) Imbach) as ingredients for functional foods or dietary supplements. Int J Med Mushrooms 4:88-94. https://doi.org/10.1615/IntJMedMushr.v4.i2.100

Xie C, Gong W, Yan L, Zhu Z, Hu Z, Peng Y (2017) Biodegradation of ramie stalk by Flammulina velutipes: mushroom production and substrate utilization. AMB Expr 7:171. https://doi.org/10.1186/s13568-017-0480-4

Yamanaka K (2017) Cultivation of mushroom in plastic bottles and small bags. In: Zied DC, Pardo-Giménez A (eds) Edible and medicinal mushrooms: technology and applications. Wiley, Hoboken, pp 385-413. https://doi. org/10.1002/9781119149446.ch15

Zarenejad F, Yakhchali B, Rasooli I (2012) Evaluation of indigenous potent mushroom growth promoting bacteria (MGPB) on Agaricus bisporus production. World J Microbiol Biotechnol 28(1):99-104. https://doi. org/10.1007/s11274-011-0796-1

Zervakis Gl, Koutrotsios G (2017) Solid-state fermentation of plant residues and agro-industrial wastes for the production of medicinal mushrooms. In: Agrawal D, Tsay HS, Shyur LF, Wu YC, Wang SY (eds) Medicinal plants and fungi: recent advances in research and development. Medicinal and aromatic plants of the world, vol 4. Springer, Singapore, pp 365-396. https:// doi.org/10.1007/978-981-10-5978-0_12

Zervakis Gl, Koutrotsios G, Katsaris P (2013) Composted versus raw olive mill waste as substrates for the production of medicinal mushrooms: an assessment of selected cultivation and quality parameters. Biomed Res Int, Article ID: 546830. https://doi.org/10.1155/2013/546830

Zhang Y, Geng W, Shen Y, Wang Y, Dai YC (2014) Edible mushroom cultivation for food security and rural development in China: bio-innovation, technological dissemination and marketing. Sustainability 6(5):2961-2973. https ://doi.org/10.3390/su6052961

Zhou Q, Tang X, Huang Z, Song P, Zhou J (2010) Novel method for cultivating Agaricus blazei. Acta Edulis Fungi 17:39-42

Zied DC, Savoie JM, Pardo-Giménez A (2011) Soybean the main nitrogen source in cultivation substrates of edible and medicinal mushrooms. In: El-Shemy HA (ed) Soybean and nutrition. InTech Open Access, Rijeka, pp 433-452

Zied DC, Cardoso C, Pardo-Giménez A, Dias E, Zeraik ML, Pardo JE (2018) Using of appropriated strains in the practice of compost supplementation for Agaricus subrufescens production. Front Sustain Food Syst. https://doi. org/10.3389/fsufs.2018.00026

\section{Submit your manuscript to a SpringerOpen ${ }^{\odot}$ journal and benefit from:}

- Convenient online submission

- Rigorous peer review

- Open access: articles freely available online

- High visibility within the field

- Retaining the copyright to your article

Submit your next manuscript at springeropen.com 